\title{
THE DECOMPOSITION OF RUSSIA'S GDP GROWTH RATE IN 1999-2015
}

\author{
S.Drobyshevsky, M.Kazakova
}

The results of the estimates obtained using the Gaidar Institute method of decomposing Russia's GDP growth rates show that in 2015 all of the components of economic growth rates will make them negative. Furthermore, the current economic contraction is mostly of structural nature induced by the contraction of labor force and capital, as well as the stagnation of the total factor productivity. Additionally, in 2015, the average annual price of crude oil is more likely to fall below the long-time average annual, thereby making negative the foreign trade component of GDP growth rates. The market-determined component of GDP growth rates in 2015 will remain negative and even lower than that in 2014, being indicative of a stronger cyclical economic contraction in Russia. Therefore, the actual GDP appears to be below the potential value.

Since about the mid last year, the expert community has been actively involved in downgrading the forecast on Russia's economic growth in 2015. For example, unlike the forecasts made in July 2014, with growth rates varying within a range of $1-2 \%$ year-over-year, the recent forecasts predict an economic contraction varying from $0.2 \%$ to $5 \%$.

According to the recent (January) version of the Ministry of Economic Development official forecast ${ }^{1}$, Russia's GDP is expected to see a decline of $3 \%$ yearover-year in 2015, with an average annual crude price being $\$ 50$ per barrel. As far as production factors are concerned, they are going to see negative dynamics: labor force will contract by $0.9 \%$ (to 67,4 million persons in 2015 from 67.9 million in 2014), while investment will decline by $13.7 \%$; net capital outflows will run at $\$ 115 b n$.

It is our opinion that the economic contraction forecast for 2015 is not too pessimistic because of the negative dynamics of the key factors having an effect on the dynamics of GDP. These factors can be identified using the method we suggest, which is based on the method of decomposing the macroeconomic indicators into their structural, foreign trade, and market-determined (business cycle and random shocks) components which is applied in developed countries (OECD), except that it has been refined to take account of the Russian economy peculiarities. These peculiarities imply a heavy reliance on foreign trade trends approximable through the dynamics of global crude oil prices.

Russia's GDP actual, structural, and foreign trade growth rate, as well as the market-determined component of the same (i.e. the sum of the business cycles and random shocks components) are shown in Fig. 1. While estimating the foregoing components of GDP growth rates, we drew on the initial estimate of Russia's economic growth made by the Federal

1 http://economy.gov.ru/minec/activity/sections/macro/prognoz
State Statistics Service (Rosstat) and the IMF's global crude price estimate in 2014; in addition, we drew on the January version of the Ministry of Economic Development's official forecast.

According to our estimates, the structural component is going to decline this year (to 1\% in 2015 from $1.3 \%$ in 2014 , Fig. 1), which is perfectly predictable, because labor and investment are contracting, the economy is facing cash outflows rather than inflows.

The negative foreign trade component of Russia's GDP growth rates in $2015(-1.1 \%)$ can be explained by the logic of our method of decomposition: the worsening of the terms of trade (a fall in crude oil prices to $\$ 50$ per barrel) makes the actual price fall below the long-time average annual (\$86 per barrel).

As shown in Fig. 1, the market-determined component of Russia's GDP growth rates in 2015 will remain negative and also decline compared to that in 2014,

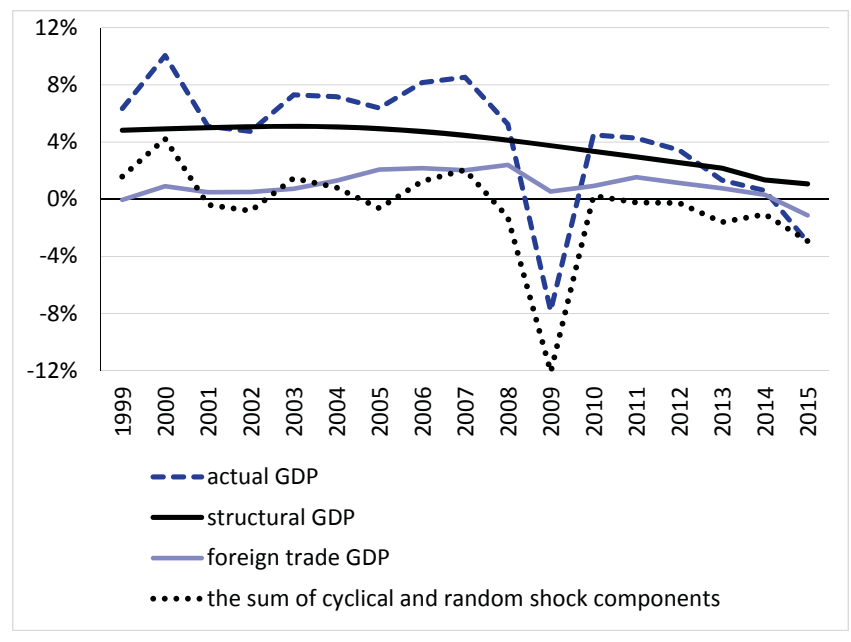

Source: The Federal State Statistics Service (Rosstat), the Ministry of Economic Development (MED), the IMF, the estimates made by the authors.

Fig. 1. The actual, structural, foreign trade, and cyclical growth rates of GDP,

$\%$ year-over-year, 1999-2014, 2015 (forecast) 
which leads to the conclusion of increasing cyclical contraction in the Russian economy in 2015.

In 2015, the output gap resulting from the decomposition of Russia's GDP growth rates appears to be negative (Fig. 2), being indicative of the fact that there is no economic growth factors for the time being.

Based on our estimates, the Russian economy in 2014 got closer to its production possibility frontier (i.e. the actual growth rate of GDP was near to its potential value). Under the circumstances, stimulating fiscal and monetary policies are inefficient. However, with a negative gap in 2015, the actual output appeared to be less than the potential one, in which case, stimulating monetary and fiscal policies would have a positive effect on the economy in terms of higher economic growth rates ${ }^{1}$. At the same time, it is worthwhile noting that this effect should not be expected to last long. The support to import substitution and the manipulation with interest rates or the ruble's exchange rate can indeed have some impact on GDP growth rates, but within a very short period of time, because the foregoing factors are not essential for economic growth.

1 A more detailed description of the method of decomposing Russia's GDP growth rates and the interpretation of the results we obtained can be found.in the article written by Sinelnikov-Murylev S.,Drobyshevskiy S., Kazakova M. The decomposition of Russia's GDP growth rates in 1999-2014 // Ekonomicheskaya Politika. 2014. No. 5. pp. 7-37, and http://iep.ru/ru/publikatcii/7125/publication.html

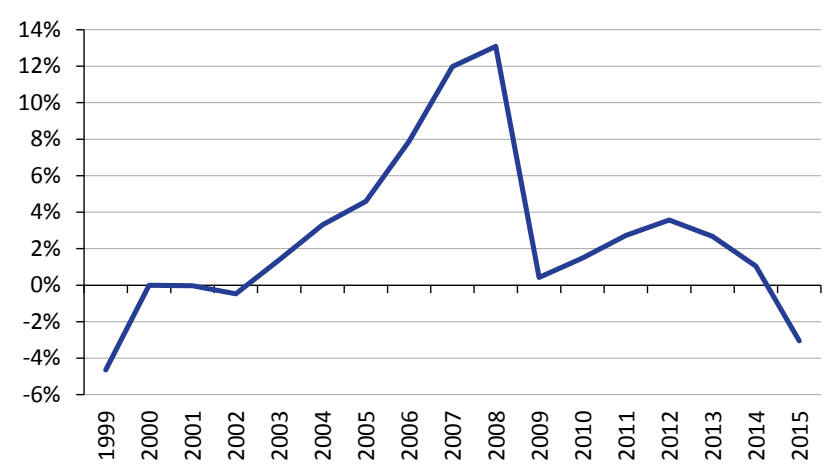

Source: the estimates made by the authors.

Fig. 2. The output gap in the Russian economy (\%), 1999-2014, 2015 (forecast)

In that context, the measures aimed at enhancing the total factor productivity should lay the foundation for structural reforms, diversification of the Russian economy and consequently a long-term economic growth. The foregoing measures are aimed at enhancing the quality of institutions and business environment, reducing corruption, undertaking a judicial and law enforcement reform, removing the administrative barriers and reducing monopolization of the market, attracting investment in the transport infrastructure, undertaking a quality social reform (including education, healthcare and pension provision), etc. 